\title{
MICROMORPHOLOGY OF STAMENS OF SOME SPECIES OF THE GENUS SANSEVIERIA PETAGNA (ASPARAGACEAE)
}

\author{
MaŁgorzata Klimko, Ilona Wysakowska, Paul Wilkin, Justyna Wiland-Szymańska
}

\begin{abstract}
M. Klimko, I. Wysakowska, Department of Botany, Poznań University of Life Sciences, Wojska Polskiego 71 C, 60-625 Poznań, Poland, e-mail: malgorzata.klimko@up.poznan.pl, ilona.wysakowska@up.poznan.pl

P. Wilkin, Royal Botanic Gardens, Kew, Richmond, Surrey, TW9 3Ab, UK, e-mail: p.wilkin@kew.org

J. Wiland-Szymańska, Department of Plant Taxonomy, Adam Mickiewicz University, Umultowska 89, 61-614 Poznań, Poland, e-mail: wiland@amu.edu.pl
\end{abstract}

(Received: February 25, 2017. Accepted: March 20, 2017)

\begin{abstract}
AвSTRACT. The paper presents in the first time the results of a micromorphological study on stamens of Sansevieria species. Flowers of 15 species obtained from herbarium specimens deposited at the Royal Botanic Gardens, Kew, the Botanical Garden Berlin-Dahlem and the Botanical Garden in Poznań were studied. Observations were conducted under a light and a scanning electron microscope. The study revealed significant differences between the outer and inner surfaces of anthers. All species have a well-defined endothecium of enlarged cells with a U-shaped or helical secondary wall thickening. The article includes descriptions and illustrations of several quantitative and qualitative features of anthers and filaments of some Sansevieria species. Our study indicates that stamen micromorphology may be taxonomically significant.
\end{abstract}

KeY WORDS: Sansevieria, anther, endothecium, filament, micromorphology, SEM, LM, taxonomy

\section{INTRODUCTION}

Sansevieria comprises ca. 60 species worldwide, mainly in dry or arid areas of the Old World tropics and subtropics (Brown 1915, Bos 1998, StAPLes \& HerbST 2005, MabBerley 2008). Africa is the center of diversity for Sansevieria (Brown 1915, MoRgENSTERn 1979, MabBerley 2008) with some species distributed in the Arabian Peninsula, South Asia and Southeast Asia (Brown 1915, Morgenstern 1979). Plants are usually xerophytic perennials, often rhizomatous, and they may be herbs, shrubs or trees (StAPLES \& HeRBST 2005). Some species are of medicinal and horticultural value (CHAHINIAN 1985, NeUwinger 1986, Bos 1998, Staples \& Herbst 2005). Based on the mode of anther dehiscence four types may be distinguished, i.e. longitudinal, transverse, poricidal and valvular. The longitudinal type is further divided into extrorse, introrse and latrorse subtypes (RADFORD et al. 1974, BANO et al. 2008). Very few reports are available on anthers of monocots (BUCHMANN 1983, ENDREss 1996, BANO et al. 2008). The value of the endothecium in taxonomy was investigated by Dormer (1962) and
NoRdenSTAm (1978) with reference to the Asteraceae, by Arora \& Tiagi (1977) in the Apiaceae, by Eyde (1977) in the Onagraceae, by Manning \& Goldblat (1990) in the Iridaceae and Noel (1983) in various species.

The present study was carried out to provide information on anther types of Sansevieria species based on their mode of dehiscence, microornamentation of anthers and filaments.

\section{MATERIAL AND METHOD}

The studied flowers of 15 Sansevieria species were obtained from herbarium specimens deposited at the Royal Botanic Gardens, Kew (K), the Botanical Garden Berlin-Dahlem (B) and the Botanical Garden in Poznań (BG AMU). A list of the analysed taxa, with their affiliation to sections and subsections, is given in Table 1. A total of 10 stamens per specimen were used for these measurements. The stamens were examined using a light microcope (LM) and a scanning electron microscope (SEM). For the LM observations (anther length and endothecial wall thickening) the 
Table 1. A list of the analysed species

\begin{tabular}{|c|c|c|c|c|}
\hline Section & Subsection & Species & Country of origin & Voucher \\
\hline Sansevieria & Sansevieria & "S. hyacinthoides (L.) Druce & South Africa & Schlieben $10570(\mathrm{~K})$ \\
\hline Sansevieria & Sansevieria & S. parva N.E. Br. & $\begin{array}{l}\text { East Africa } \\
\text { unknown }\end{array}$ & $\begin{array}{l}\text { cult., Kew, Pfenning } 1034(\mathrm{~K}) \\
\text { cult. BG AMU, I_I001_004_0000_6977_1231 }\end{array}$ \\
\hline Sansevieria & Sansevieria & S. parva N.E. Br. (dooneri) & Kenya & cult. Kew, Brandham \& Cutler 01929 \\
\hline Sansevieria & Sansevieria & S. trifasciata Prain & Cameroon & Lowe $3035(\mathrm{~K})$ \\
\hline Sansevieria & Sansevieria & S. roxburghiana Schult. \& Schult. & unknown & cult. Kew, Marchward 631310 \\
\hline Sansevieria & Hastifolia & "S. cylindrica Bojer ex Hook & Angola & s. coll. s. n. (K) K000204052 \\
\hline Sansevieria & Hastifolia & S. pearsonii N.E. Br. & Zambia & Fanshawe $6946(\mathrm{~K})$ \\
\hline Sansevieria & Stolonifera & "S. suffruticosa N.E. Br. & Kenya & Tweedie 3666 (K) \\
\hline Dracomima & & $\begin{array}{l}\text { S. arborescens Cornu Gérôme et } \\
\text { Labroy }\end{array}$ & Tanzania & Faulkner 1827 (K) \\
\hline Dracomima & & S. bagamoyensis N.E. Br. & Tanzania & Bally 13309 (B) \\
\hline Dracomima & & "S. ehrenbergii Schweinf. ex Baker & Kenya & Hensley 1256 (K) \\
\hline Dracomima & & $\begin{array}{l}\text { S. perrotii Warb. } \\
\text { (S. robusta N.E. Br.) }\end{array}$ & Kenya & $\begin{array}{l}\text { Pfenning, Herford } \\
\text { Pf } 1023 \text { S(B) }\end{array}$ \\
\hline Dracomima & & S. powellii N.E Br. & Kenya & Rauh Ke 875 (B) \\
\hline Cephalantha & & "S. kirkii Baker & Tanzania & Faulkner 1989 (K) \\
\hline Cephalantha & & S. sambiranensis Perrier & Madagascar & Phillipson 2023 (K) \\
\hline
\end{tabular}

*Type species for the section or subsection.

anthers were boiled in water. The SEM observations (anther shape, outher and inner surface of anthers, as well as surface of filament) were made on air-dried anthers and filaments. Anther length was measured under a Brinella microscope, endothecium cells were observed using an Olympus microscope model BX 40 equipped with a camera. For the anther length the minimal and maximal values of characteristics as well as arithmetical means and the coefficient of variability were calculated. Micrographs were taken with a SEM type EVO 40 microscope (Carl Zeiss, Jena, Germany) at an accelerating voltage of $15 \mathrm{kV}$, at the Confocal and Electron Microscopy Laboratory, the Faculty of Biology, the Adam Mickiewicz University, Poznań, Poland. Prior to observations the prepared material was sputtered with gold using an SCB 050 ion sputter. The study was documented with photographs taken during observations, primarily at a magnification ranging from $\times 100$ to $\times 200$ for anther shape and $\times 2500$ for the epidermal sculpture of anthers and filaments. SEM micrographs were used mainly to investigate the overall shape, type of sculpturing, and to obtain more detailed information on the sculpturing. Micromorphological features of anthers were observed in their outer and inner surfaces. The terminology of epicuticular waxes was applied following BARTHLOTT (1981).

\section{RESULT AND DISCUSSION}

Generally anthers were dorsifixed, elongate-elliptic, dehiscing via longitudinal slits, latrorse. The shape of anthers show low variability (Figs 1-4). This type of anthers was reported in the families Asparagaceae, Cyperaceae, Juncaceae and Potamogetonaceae (BANo et al. 2008). Buchmann (1983) also observed some monocot families with at least one taxon, in which anthers dehisce by pores or apical slits. Anther length ranged from 1.25 (S. kirkii, S. roxburghiana and S. sambiranensis) to $1.98 \mathrm{~mm}$ (S. hyacinthoides and S. pearsonii). The average length ranged from 1.28 to $1.77 \mathrm{~mm}$. Coefficients of variability ranged from 2.6 (S. parva) to 18.4 (S. pearsonii) (Table 2). SEM investigation at the higher magnification of outer surface of anthers revealed one type of anther sculpture-reticulate in all studied species (Figs 5-16). The cell shapes were polygonal, irregular elongate in one direction. The anticlinal walls which formed a boundary between the epidermal cells were depressed below the outer tangential surfaces cells (Figs 5-16). The periclinal cell walls of the species were flat (Figs 5, $8-10,12,14$ ), or convex (Figs 13, 16). The cuticle ornamentation on the outher surface of anthers (Table 2) was rugulate-perforate (Figs 5, 6, 8, 10, 14), rugulate (Figs 11, 13), striate (Fig. 7), striate-perforate (Fig. 9), striate-rugulate (Fig. 12) and granulate-rugulate (Figs 15, 16). There were significant differences between outer and inner surface of anthers in all studied species. The epidermal cells in SEM of the inner surface of anther show that the surface was covered by orbicule (Figs 17, 18). The endothecium cells may be more or less isodiametric, broadly fusiform or elongated and arranged paralleled. The orientation is usually related in a specific way to the long axis of the anther. All species have a well-defined endothecium of enlarged cells with a U-shaped or helical secondary wall thickening and there was a considerable range in cell size (Figs 19-26). Our results are in agreement with the results obtained by the others authors UntaWale \& Bhasin (1973), French (1985, 1986), Manning \& Goldblat (1990). The filament in all species was filiform (Figs 1-4). The surface 

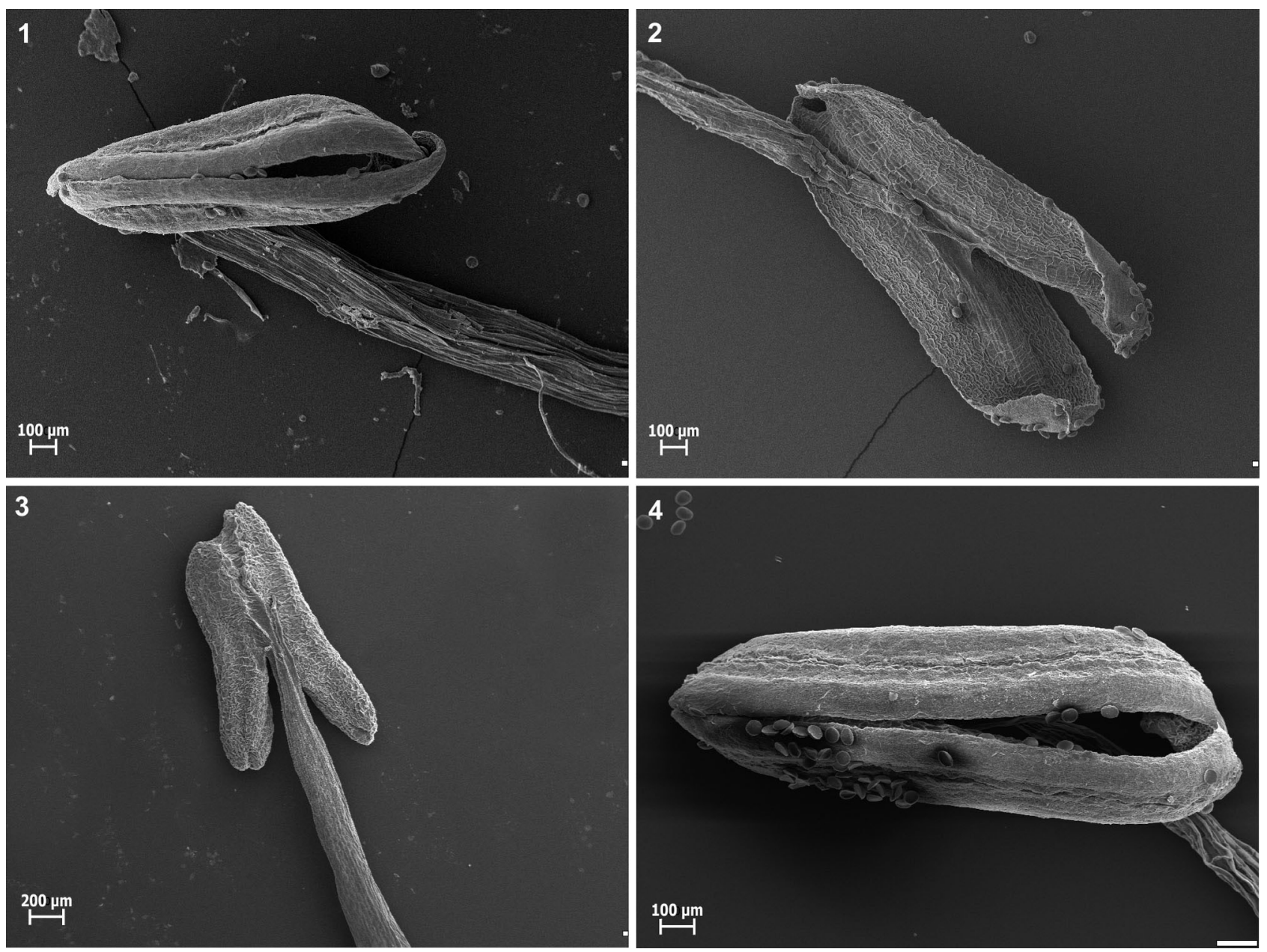

Figs 1-4. SEM micrographs of stamens of Sansevieria: (1) S. bagamoyensis, (2) S. powelii, (3) S. suffruticosa, (4) S. trifasciata

Table 2. Quantitative and qualitative features of studied traits of stamens for the Sansevieria species analysed in the study

\begin{tabular}{lrrrrll}
\hline \multirow{2}{*}{ Species } & \multicolumn{3}{c}{ Length of anther $(\mathrm{mm})$} & & \multicolumn{2}{c}{ Ornamentation } \\
\cline { 2 - 6 } & min. & max. & mean $( \pm \mathrm{SD})$ & $\mathrm{cv}$ & $\begin{array}{c}\text { cuticle on the outer } \\
\text { surface of anther }\end{array}$ & surface of filament \\
\hline Sansevieria arborescens & 1.51 & 1.72 & $1.62(0.07)$ & 4.8 & rugulate, perforate & thin striate \\
S. bagamoyensis & 1.60 & 1.76 & $1.65(0.06)$ & 3.9 & rugulate & striate \\
S. cylindrica & 1.45 & 1.87 & $1.69(0.17)$ & 9.9 & rugulate, perforate & rugulate-striate \\
S. dooneri & 1.48 & 1.95 & $1.66(0.17)$ & 10.5 & striate & smooth \\
S. ehrenbergii & 1.38 & 1.52 & $1.42(0.06)$ & 4.3 & rugulate, perforate & striate \\
S. hyacinthoides & 1.48 & 1.98 & $1.75(0.18)$ & 10.7 & rugulate, perforate & striate \\
S. kirkii & 1.25 & 1.87 & $1.52(0.28)$ & 17.9 & slightly striate, perforate & smooth-rugulate \\
S. parva & 1.29 & 1.38 & $1.35((0.04)$ & 2.6 & rugulate, perforate & striate \\
S. pearsonii & 1.29 & 1.98 & $1.56(0.28)$ & 18.4 & rugulate & smooth-rugulate \\
S. perrotii & 1.32 & 1.60 & $1.45(0.11)$ & 7.4 & rugulate & striate \\
S. powelii & 1.36 & 1.51 & $1.41(0.06)$ & 6.2 & striate-rugulate & striate \\
S. roxburghiana & 1.25 & 1.67 & $1.46(0.20)$ & 13.7 & rugulate, perforate & striate \\
S. sambiranensis & 1.25 & 1.38 & $1.28(0.05)$ & 4.4 & rugulate-granulate & rugulate-granulate, perforate \\
S. suffruticosa & 1.45 & 1.79 & $1.57(0.13)$ & 8.4 & rugulate & striate \\
S. trifasciata & 1.61 & 1.93 & $1.77(0.16)$ & 9.3 & granulate-rugulate & thin striate-rugulate \\
\hline
\end{tabular}



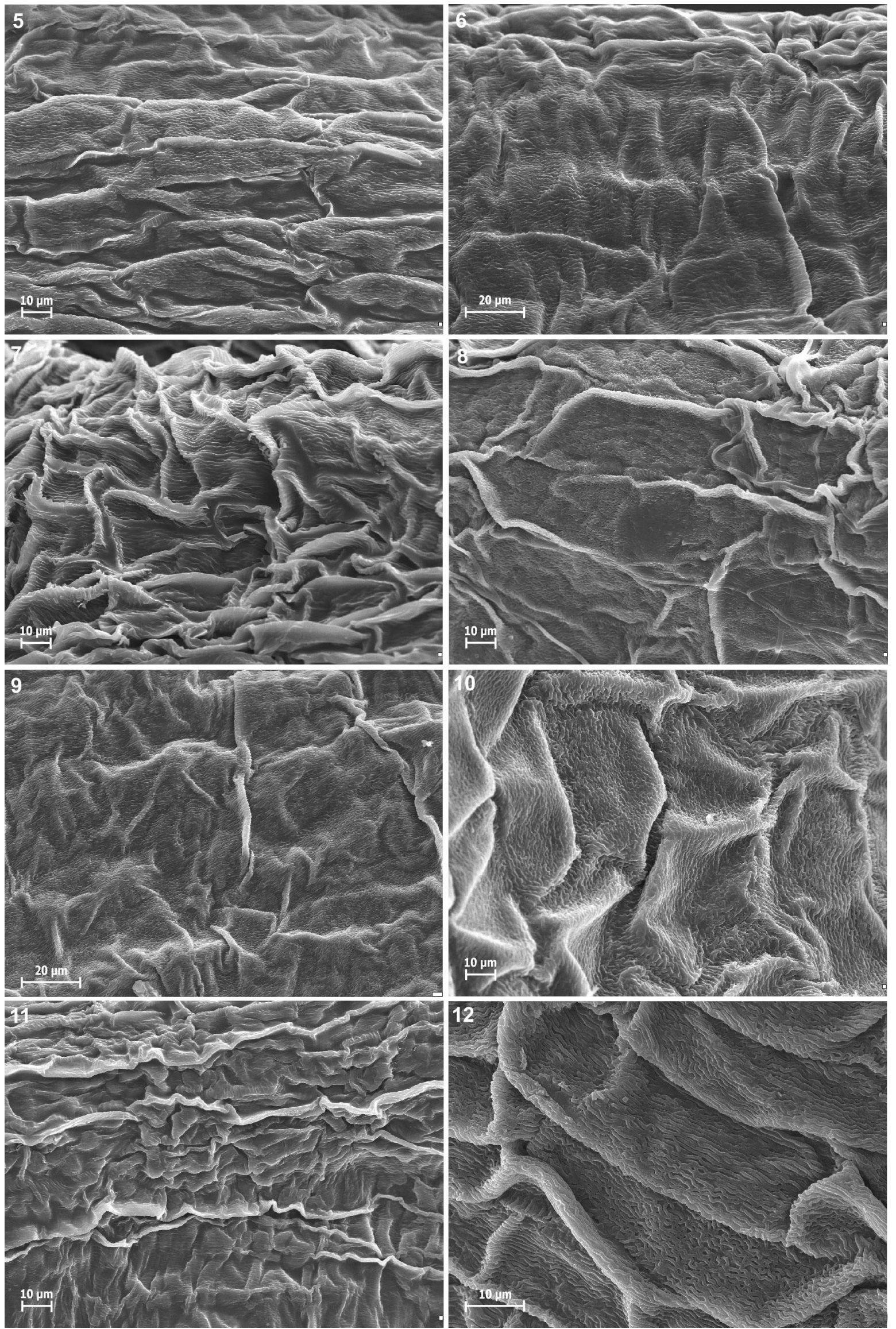

Figs 5-12. SEM. Outer surface of anther of Sansevieria: (5) S. arborescens, (6) S. cylindrica, (7) S. dooneri, (8) S. hyacinthoides, (9) S. kirkii, (10) S. parva, (11) S. pearsonii, (12) S. powelii 

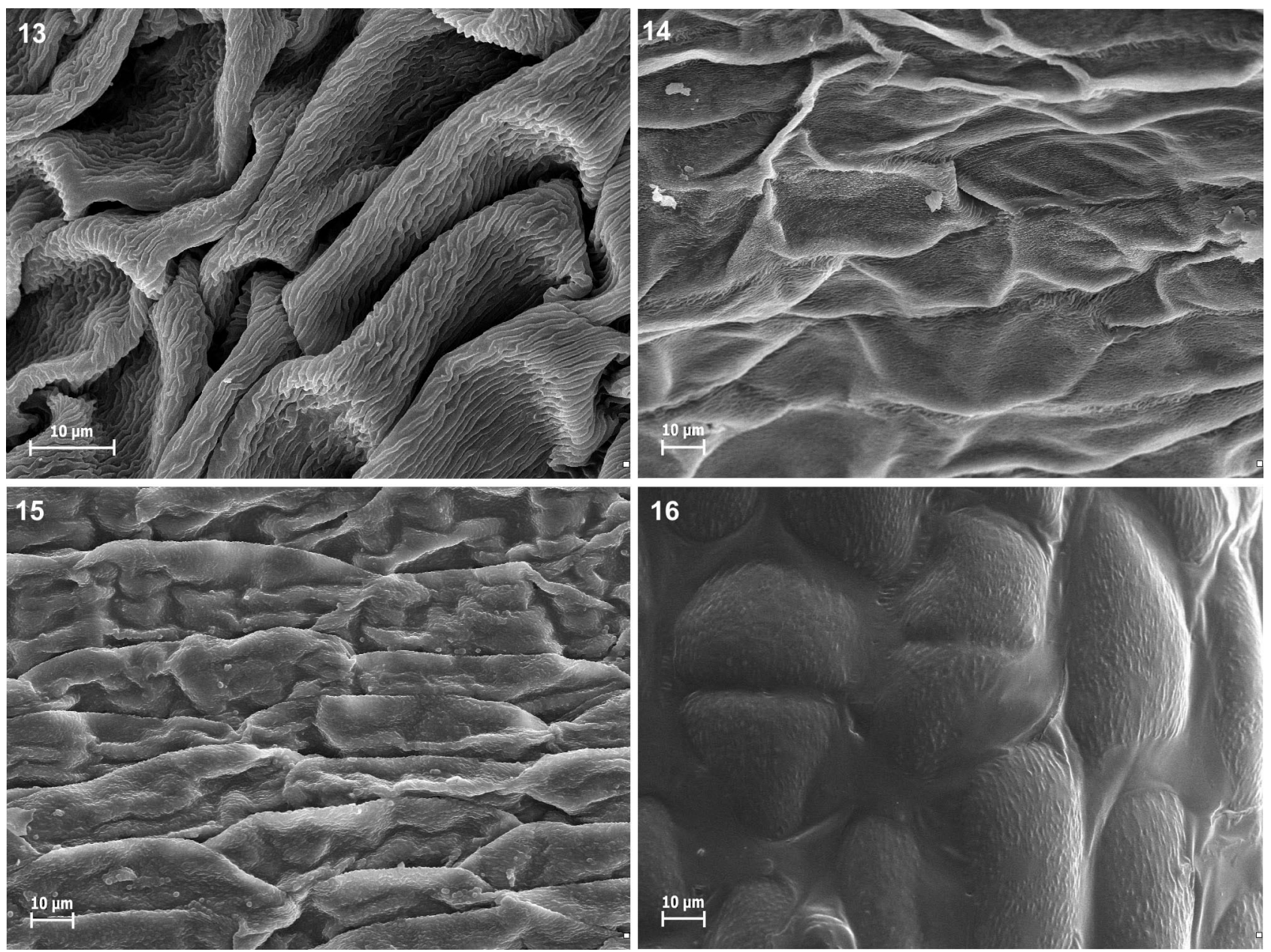

Figs 13-16. SEM. Outer surface of anther of Sansevieria: (13) S. perrotii, (14) S. roxburghiana, (15) S. sambiranensis, (16) S. trifasciata

of filament varied from (Table 2) smooth (Fig. 30), smooth-rugulate (Fig. 33), rugulate-striate (Fig. 29), striate (Figs 27, 28, 31, 32, 35, 36) to rugulate-granulate-perforate (Fig. 34). To date $S$. dooneri has been treated as a synonym of $S$. parva (MANSFelD 2015). Both species have soft, flat leaves without wall bands for water storage (KolLER \& Rost 1988) and without cuticular rims around stomata (KLIMKo et al. unpublished results). Both species differ in the epidermal microornamentation of staminal filaments. Ornamentation of filaments in $S$. dooneri was smooth (Fig. 30 ) and in S. parva it was striate (Fig. 33, Table 2). The present study is the first to investigate the anther and filament surface of Sansevieria and detailed
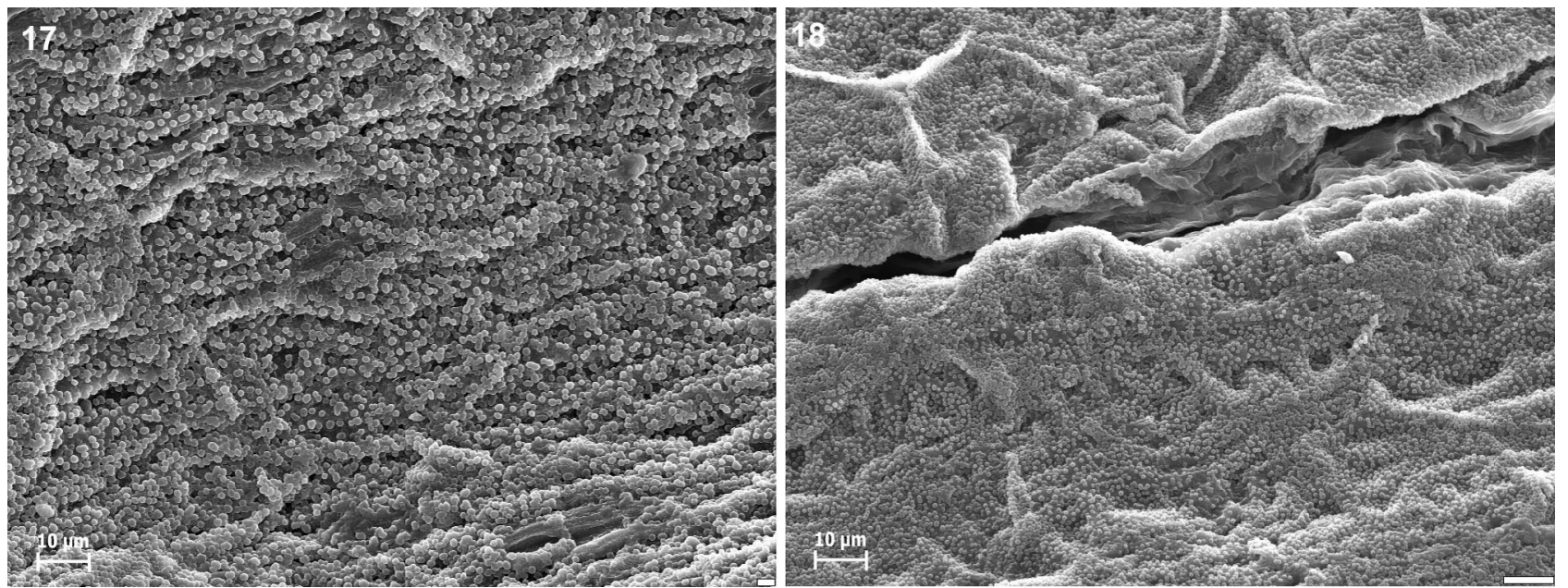

Figs 17-18. SEM. Inner surface of anther of Sansevieria: (17) S. hyacinthoides, (18) S. trifasciata 

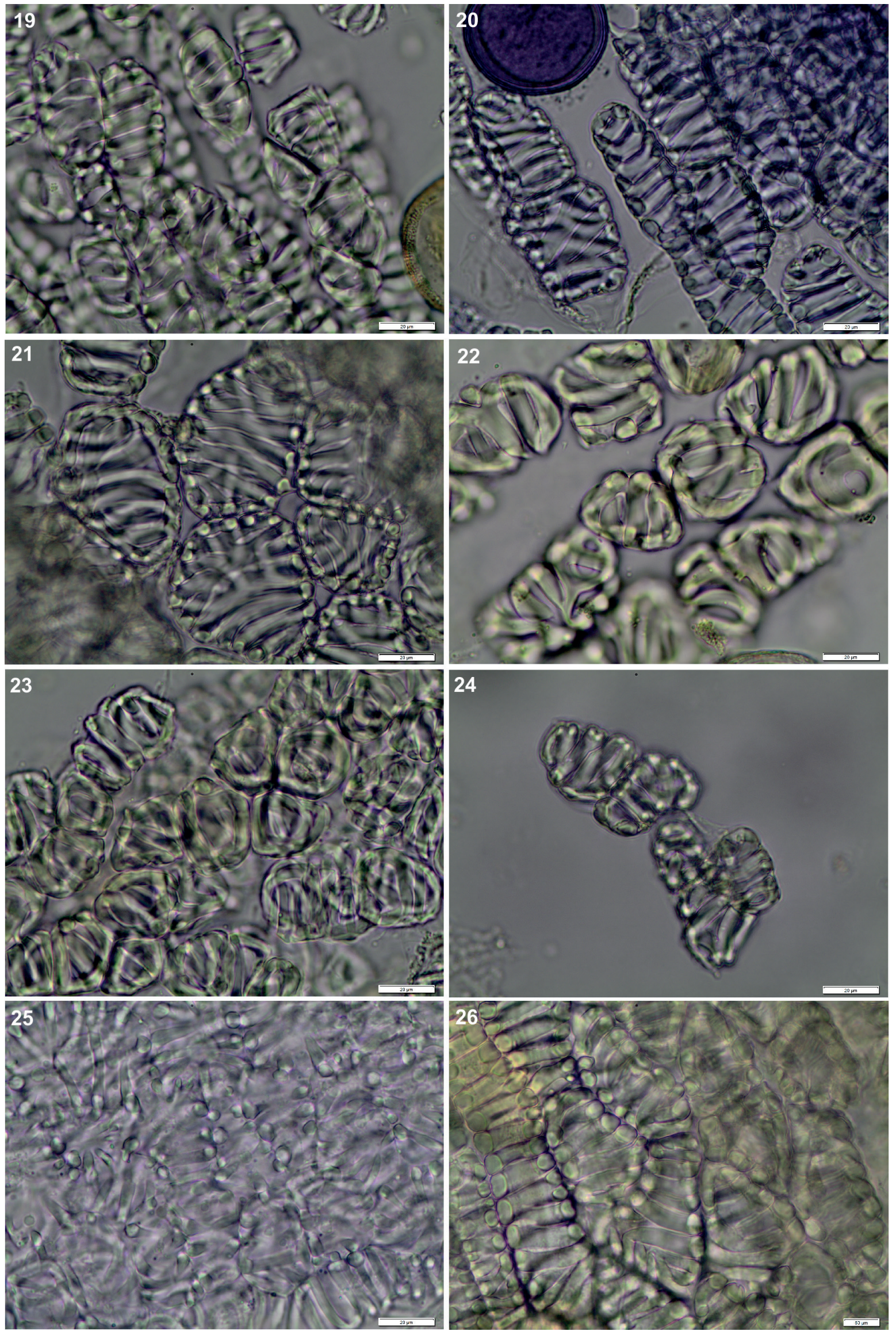

Figs 19-26. LM. Endothecial wall thickening of Sansevieria: (19) S. arborescens, (20) S. bagamoyensis, (21) S. cylindrica, (22) S. hyacinthoides, (23) S. kirkii, (24) S. pearsonii, (25) S. sambiranensis, (26) S. trifasciata 

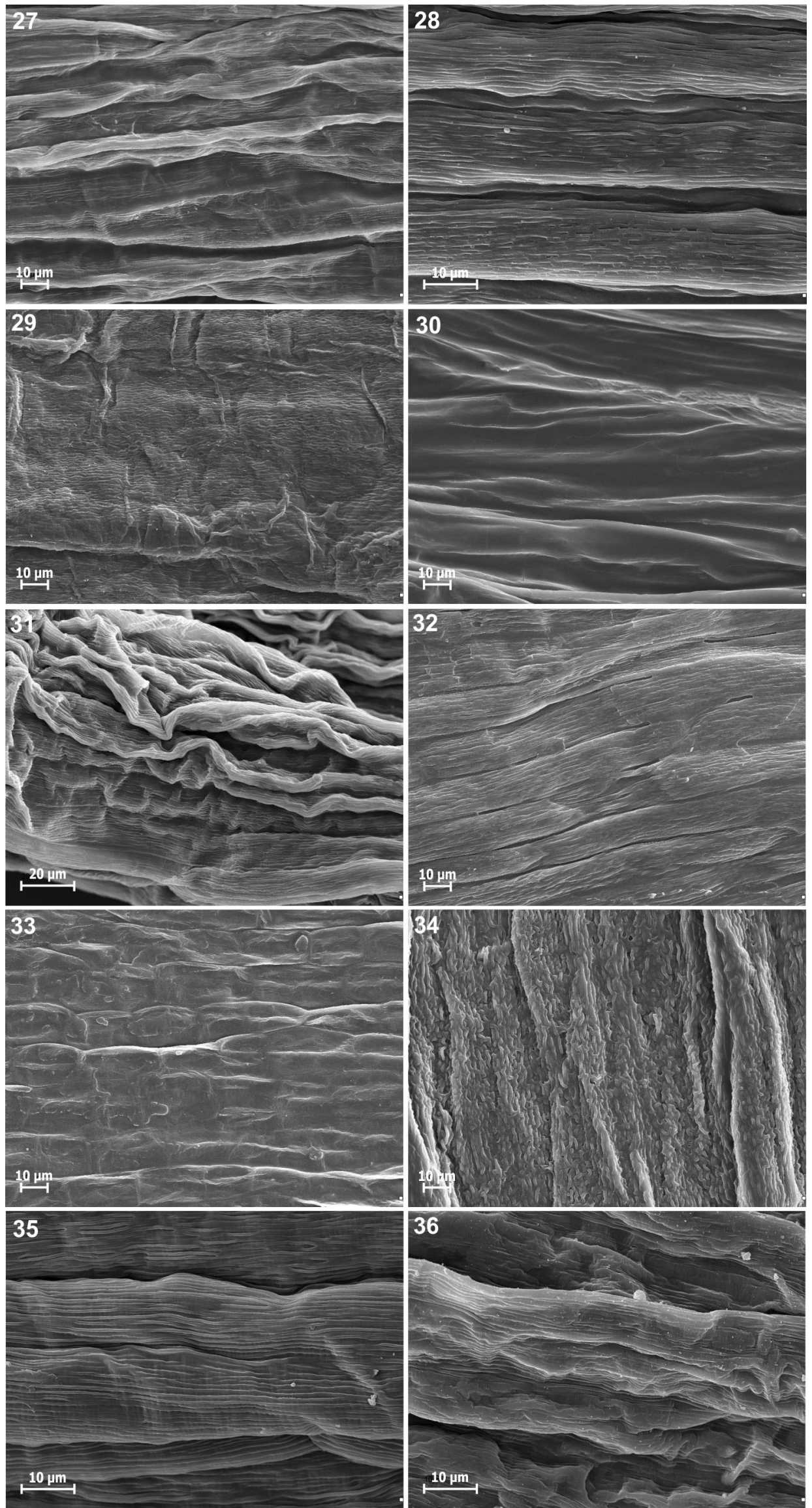

Figs 27-36. SEM. Surface of filament of Sansevieria: (27) S. arborescens, (28) S. bagamoyensis, (29) S. cylindrica, (30) S. dooneri, (31) S. hyacinthoides, (32) S. parva, (33) S. pearsonii, (34) S. sambiranensis, (35) S. perrotii, (36) S. powelii 
observations provided new data. We conclude that $S$. dooneri and S. parva are not one species, but should be divided into two lowest taxa in the rank of varieties (S. parva var. dooneri and var. parva).

\section{ACKNOWLEDGEMENTS}

We would like to express our gratitude to Wojciech Klimko for his assistance with computer recording. The authors would like to thank two anonymous reviewers for their suggestions and comments on an earlier version of the manuscript. This work was carried out with the financial support from the National Science Center (grant no. N N303 807540), and the Department of Botany, the Poznań University of Life Sciences and the Faculty of Biology, the Adam Mickiewicz University in Poznań.

\section{REFERENCES}

Arora K., Tiagi B. (1977): The role of the endothecium in the identification of Umbellifers. Current Science 46: 531.

Bano R., Abid R., QAiser M. (2008): Anther types of the monocot within flora of Karachi, Pakistan. Pakistan Journal of Botany 40(5): 1839-1849.

BARTHLOtT W. (1981): Epidermal and seed surface characters of plants: Systematic applicability and some evolutionary aspects. Nordic Journal of Botany $1: 345-355$.

Bos J.J. (1998): Draceanaceae. In: K. Kubitzki (ed.). The families and genera of vascular plants 3 . Monocotyledons, Lilianae (except Orchidaceae). Springer-Verlag, Heidelberg, New York.

Brown N.E. (1915): Sansevieria. A monograph of all the known species. Bulletin of Miscellaneous Information (Royal Botanical Gardens, Kew) 5: 185-261.

BuCHMANN S.L. (1983): Buzz pollination in Angiosperms. In: C.E. Jones, R.J. Little (eds). Handbook of experimental pollination biology. Scientific Academic Editions, New York: 73-113.

Chahinian B.J. (1985): The Sansevieria trifasciata dwarf cultivars: a beginning with no end. Cactacae Succulent Journal (Los Angeles) 57: 199-203.

Dormer K.J. (1962): The fibrous layer in the anthers of Compositae. New Phytologist 61: 150-153.

ENDRESS P.K. (1996): Diversity and evolutionary trends in angiosperm anthers. In: W.G. D'Arey,
R.C. Keating (eds). The Anther (Form, function and phylogeny). Cambridge University Press, Cambridge.

Eyde R.H. (1977): Reproductive structures and evolution in Ludwigia (Onagraceae). 1. Androecium placentation, merism. Annals of the Missouri Botanical Garden 64: 644-655.

FrenCH J.C. (1985): Patterns of endothecial wall thickenings in Araceae: subfamilies Pothoideae and Monsteroideae. American Journal of Botany $72(3)$ : 472-486.

FrenCH J.C. (1986): Patterns of endothecial wall thickenings in Araceae: subfamilies Colocasioideae, Aroideae and Pistioideae. Botanical Gazzete 47(2): 166-179.

Koller A., Rost T. (1988): Leaf anatomy in Sansevieria (Agavaceae). American Journal of Botany 75: 615-633.

Mabberley D.J. (2008): Mabberley's plant book. Cambridge University Press, Cambridge.

Manning J.C., Goldblat P. (1990): Endothecium in Iridaceae and its systematic implications. American Journal of Botany 17(4): 527-530.

Mansfeld P. (2015): Die Systematik der Gattung Sansevieria (Asparagaceae) - ein aktueller Stand. Sansevieria Online 3/1: 20-29.

MorgenSTERn K.D. (1979): Sansevierias in pictures and words. Illertalen Offsetdruck and Verlag GMBH, Kempten, Germany.

NeuWINGER H. (1986): African ethnobotany; poisons and drugs: chemistry, pharmacology, toxicology. Chapman Hall, Weinheim.

Noel A.R.A. (1983): The endothecium - a neglected criterion in taxonomy and phylogeny? Bothalia 14(3, 4): 833-838.

Nordenstam B. (1978): Taxonomic studies in the tribe Senecioneae (Compositae). Opera Botanica 44: 3-83.

Radford A.E., Dickison W.C., Massey J.R., Ritchi Bell C. (1974): Vascular Plant Systematics. Harper \& Row Publisher, New York.

Staples G.W., Herbst D.R. (2005): A tropical garden flora. Bishop Museum Press, Honolulu, Hawaii, USA.

UntaWALE A.G., Bhasin R.K. (1973): On endothecial thickenings in some monocotyledonous families. Current Science 42: 398-400. 